\title{
Proceeding
}

Supplementary Issue: Spring Conferences of Sports Science. III International Congress on Research and Didactics of Physical Education, 15-16 March 2018. Granada, Spain

\section{Emotional intelligence and motivation in athletes of different modalities}

\author{
MANUEL CASTRO-SÁNCHEZ 19 , RAMÓN CHACÓN-CUBEROS², FÉLIX ZURITA-ORTEGA ${ }^{3}$, PILAR \\ PUERTAS-MOLERO ${ }^{3}$, MARÍA SÁNCHEZ-ZAFRA ${ }^{3}$, IRWIN RAMÍREZ-GRANIZO ${ }^{3}$ \\ ${ }^{1}$ Department of Education, University of Almería, Spain \\ ${ }^{2}$ Department of Integrated Didactics, University of Huelva, Spain \\ ${ }^{3}$ Department of Didactics of Musical, Plastic and Corporal Expression, Faculty of Education Sciences, \\ University of Granada, Spain
}

\begin{abstract}
This research study aims at analysing motivational climate and emotional intelligence in athletes of different categories of sports according to their gender and category of sport practised, on a sample of 372 athletes aged between 18 and 50, evaluated by means of the Perceived Motivational Climate in Sport Questionnaire (PMCSQ-2), the Schutte Self Report Inventory (SSRI) questionnaire on emotional intelligence in sports and a self-registration sheet which measured the variables of gender and category of sports practised. Results show that in the sample of athletes analysed there is a clear orientation towards task, being greater the orientation towards ego in men and standing out orientation towards task in athletes of individual categories with contact. Regarding emotional intelligence, the athletes analysed showed high ratings in the four dimensions, achieving self-emotional management the highest scores, whereas emotion utilisation obtains the lowest grade; no association has been found between emotional intelligence and gender of respondents; as for the category of sports, athletes who practise collective sports with contact are the ones to better handle their emotions. Emotional intelligence correlates directly and significantly with motivational task-oriented

\footnotetext{
Corresponding author. Room 31. Scientific Technical Building III Mathematics and Computers (CITE III). Department of Education. University of Almería. Ctra. Sacramento, s/n. CP. 04120 La Cañada (Almería), Spain.

E-mail: mcastros@ual.es

Supplementary Issue: Spring Conferences of Sports Science. III International Congress on Research and Didactics of Physical Education, 15-16 March 2018. Granada, Spain.

JOURNAL OF HUMAN SPORT \& EXERCISE ISSN 1988-5202

(c) Faculty of Education. University of Alicante

doi: 10.14198/jhse.2018.13.Proc2.01
}

S162 | $2018 \mid$ Proc2 | VOLUME 13

(C) 2018 University of Alicante 
climate, but not with ego-oriented climate. Key words: MOTIVATIONAL CLIMATE; EMOTIONAL INTELLIGENCE; SPORT; CATEGORY OF SPORTS.

\section{Cite this article as:}

Castro-Sánchez, M., Chacón-Cuberos, R., Zurita-Ortega, F., Puertas-Molero, P., Sánchez-Zafra, M., \& Ramírez-Granizo, I. (2018). Emotional intelligence and motivation in athletes of different modalities. Journal of Human Sport and Exercise, 13(2proc), S162-S177. doi:https://doi.org/10.14198/ihse.2018.13.Proc2.01 


\section{INTRODUCTION}

Currently, psychology of sports has become particularly relevant, focusing on analysing factors and psychological processes in athletes, during training sessions, precompetitive training or during the competition (Thelwell, Wood, Harwood, Woolway \& Van Raalte, 2018).

Contribution of sports psychologists is focused on the improvement of the athletes' cognitive abilities in order to maximise their performance, therefore it is necessary to study certain variables such as motivation, leadership or strategies to confront stressful situations, among others, considering influence of these factors on the athlete's performance, therefore becoming an essential object of study for specialists in sports psychology (Hacker \& Mann, 2017; Stanger, Kavussanu \& Ring, 2017).

Connection between psychological aspects and sports performance has been confirmed by means of numerous investigations which verify that the control of psychological factors influences athlete's development, this in turn creating an interest for professional sports to control these factors aiming at improving results (Bennett \& Maynard, 2017; Rodríguez, Gómez, \& Álvarez, 2017).

Along the same lines, Anshel \& Payne (2006) highlight the importance of psychological training for high performance athletes, pointing out that the training of the athlete's cognitive skills and abilities must focus on the improvement of self-control, the development of anticipation, motivation, emotion control and the nurture of confidence, among other fundamental aspects (Ong \& Griva, 2017).

In this sense, McConville, McAleer \& Hahne (2017) emphasise the importance of the influence of psychological factors in sport, indicating that psychological training in high performance athletes is as important as physical training.

The first psychological factor analysed in this research study is motivation, considered as one of the most widely studied factors in sports psychology as it is one of the most influential in order to explain human behaviour (Holden, Pugh \& Schwarz, 2017). It is a key factor influencing behaviour directly, modifying its intensity, direction and performance (Quested, Ntoumanis, Thøgersen-Ntoumani, Hagger \& Hancox, 2017).

Investigation on motivation in this research study focuses on motivational climate, which represents the set of indicators perceived by individuals in their environment, be it sporting, educational, etc., through which failure and success will be defined (Ames, 1992). In the context of sports coaches will be the ones to promote task goal orientation (mastery) or ego goal orientation (performance) depending on the standards of success used (Super, Verkooijen \& Koelen, 2018). When the coach focuses on result, he will be promoting an ego goal motivational climate (comparison between peers and outperforming others), whereas if he focuses on process (self-improvement and effort) a task goal climate will be encouraged (Almagro, 2012). Ego goal climate is directly related to high levels of anxiety in athletes, due to pressure to demonstrate their abilities and outperform others, therefore having problems in their personal development (Ellif \& Huertas, 2015). Thus, athletes will be oriented either towards task or towards ego, depending a great deal on the motivational climate promoted by the coach (Almagro, 2012).

The second psychological factor analysed is emotional intelligence, understood by Salovey \& Grenwal (2005) as a fundamental ability which enables integration of cognitive and emotional aspects effectively. Influence of emotional regulation on sports performance has been confirmed, although it does not represent one of the fundamental pillars in the athlete's psychological training, due to the lack of current scientific knowledge 
regarding the implementation of intervention programmes in emotional intelligence, misconceptions considering this factor as an inherent non trainable ability or the shortage of training time, among others (Weinberg \& Gould, 2010). Recent research indicates the need of emotional development to the same extent as cognitive aspects are worked on, being emotional aspects directly related to the athletes' aspirations to show effectiveness (Balk, De Jonge, Oerlemans \& Geurts, 2017).

Research on these psychological factors is essential in order to understand the different cognitive processes produced while training and competing. This work complements many other studies in the context of sports related to motivation and emotional intelligence in athletes.

Due to the importance of emotional and motivational factors in the context of sports and the ir connection to performance, it is fundamental to analyse the levels of motivational climate and emotional intelligence in athletes. Thus, the main goal of this research study is to analyse the relationship between emotional intelligence and motivational climate depending on gender and category of sports.

\section{METHOD}

\section{Design and participants}

This descriptive and cross sectional study has been carried out on a sample of 372 semi-professional Spanish athletes of both sexes (63.2\% men and 36.8\% women), aged between 18 and 50 ( $M=21.24 ; S D=3.096)$. The sample has been selected through a process of convenience sampling, according to categories of sports. The sample has been obtained from diverse sport clubs, eight of them running clubs, twelve football, two paddle tennis and two taekwondo clubs, requesting participation of all the clubs that would accept collaborating voluntarily. It must be pointed out that during the collection of data, not repeating individuals has been guaranteed, with the purpose of avoiding data duplication, by means of an individualised monitoring during data collection.

\section{Measures}

- Gender, distinguishing male or female, gathered in an ad-hoc questionnaire.

- Kind of sport, using an ad-hoc questionnaire, it was classified into: individual without contact, individual with contact, collective without contact and collective with contact.

- Motivational Climate (PMCSQ-2), questionnaire extracted from the original version by Newton, Duda and Yin (2000) adapted to Spanish by González-Cutre, Sicilia and Moreno (2008). This instrument is made up of 33 items rated using a Likert scale with 5 options ranging from $1=$ strongly disagree to $5=$ strongly agree. The questionnaire establishes two categories: Task oriented climate, with its categories Cooperative Learning, Effort/Improvement and Important role, on the one side, and Ego oriented Climate with its corresponding categories, Punishment for Mistakes, Unequal Recognition and Rivalry between members of the Group, on the other. The internal consistency (Cronbach's Alpha) of the instrument obtained by González-Cutre et al. (2008) in its Spanish version got a $\alpha=.90$ in Ego oriented climate ( $\alpha=.77$ in punishment for mistakes, $\alpha=.87$ in unequal recognition and $\alpha=.61$ in rivalry) and $a=.84$ in Task oriented climate ( $\alpha=.65$ in cooperative learning, $\alpha=.70$ in effort/improvement and $\alpha=.70$ in important role). In this research study we obtained $\alpha=.895$ in Ego oriented climate ( $\alpha=.929$ in punishment for mistakes, $\alpha=.912$ in unequal recognition and $\alpha=.681$ in rivalry between members of the group) and $\alpha=.937$ in Task oriented climate ( $\alpha=.839$ in cooperative learning, $\alpha=.842$ in effort/improvement and $\alpha=.867$ in important role). 
- Schutte Self Report Inventory (SSRI), it is gathered from the original questionnaire by Shutte et al. (1998) which measures emotional intelligence in a unifactorial model. Adapted by García-Coll, Graupera-Sanz, Ruiz-Pérez and Palomo-Nieto (2013) to the tetrafactorial model where other dimensions are calculated such as emotion perception, self-emotional management, heteroemotional management (managing others' emotions) and emotion utilisation. This test is a 33 item measuring instrument which evaluates the individuals' ability to identify, understand and manage self-emotions and others' emotions. Items are measured using a 5 option Likert scale, where 1 is I strongly disagree and 5 is I strongly agree. In this research study we have used the model proposed by García- Coll et al. (2013) where items 5, 28 and 33 are removed, because as they are formulated in a negative way they created a kind of response factor which disrupted the whole analysis, so the instrument used in this analysis is made up of 30 items. García-Coll et al.'s study (2013) ascertained a reliability of $\alpha=.91$ in General Emotional Intelligence, whereas other dimensions obtained: emotion perception $(\alpha=.709)$, self-emotional management $(\alpha=.77)$, heteroemotional management $(\alpha=.78)$ and emotion utilisation $(\alpha=.63)$. In this investigation we obtained similar values such as $\alpha=.912$ in general emotional intelligence, emotion perception $(\alpha=.77)$, self-emotional management $(\alpha=.739)$, heteroemotional management $(\alpha=.779)$ and emotion utilisation $(\alpha=.696)$.

\section{Procedure}

The first step was contacting each of the federations of the sports analysed in this research study in order to consult data regarding number of athletes and federated clubs. Next, we contacted the different clubs and athletes to explain the nature and aim of this research study, setting thereby the dates when the data collection was going to take place. As soon as the clubs and athletes had accepted taking part in the study, the questionnaires were completed from September to December 2016, before the training sessions, with the intention of reaching an optimal completion. After the data collection, 56 questionnaires were rejected as they were not correctly completed. This investigation has followed the line put forward by the Declaration of Helsinki (World Medical Association, 2008) relating to research projects, as well as national legislation for clinical trials (Royal Decree 223/2004 of 6 February), law on biomedical research (Law 14/2007, of 3 July) and on the protection of personal data (Law 15/1999 of 13 December).

\section{Data analysis}

Data analysis has been carried out using the statistical package IBM SPSS 23.0. In order to calculate descriptive statistics of the different variables, medians and frequencies were used. Subsequently, the relational study was carried out using T-student, one-factor ANOVA and correlations.

\section{RESULTS}

In this descriptive and cross-sectional study participated 372 athletes of both sexes $(63.2 \%$ men and 36.8 women), aged between 18 and 50 (M=21.24; SD=3.096). Regarding kind of sports, 46.2\% ( $n=172)$ practise individual sports without contact, followed by collective sports with contact $(37.9 \% ; n=141)$, collective without contact $(11.1 \% ; n=41)$ and only $4.8 \%(n=18)$ practise individual sports with contact, as Table 1 shows.

According to data in Table 1, regarding motivational climate it is confirmed that task oriented climate $(M=3.95$; $\mathrm{SD}=.70)$ and its dimensions, cooperative learning $(\mathrm{M}=4.02 ; \mathrm{SD}=.78)$, effortimprovement $(\mathrm{M}=3.91 ; \mathrm{SD}=.68)$ and important role $(\mathrm{M}=3.96 ; \mathrm{SD}=.83)$ obtain similar scores, these being highly superior to scores obtained in ego oriented climate $(M=2.30 ; S D=.79)$ and its categories, rivalry between members of the group $(M=2.65$; $S . D=.93)$, punishment for mistakes $(M=2.18 ; S D=.83)$ and unequal recognition $(M=2.25 ; S D=.91)$. 
As regards general emotional intelligence it obtained an average value of 3.84 (S.D=.46), obtaining selfemotional management the highest score $(M=3.96$; $S D=.53)$, followed by heteroemotional management $(M=3.81 ; S D=.51)$ and emotion perception $(M=3.80 ; S D=.46)$ with very similar scores. Emotion utilisation was the dimension with the lowest marks, with an average value of $3.77(\mathrm{SD}=.55)$. Scores are similar, ranging all between 3.80 and 3.96 as we can see in Table 1.

Table 1. Descriptive.

\begin{tabular}{|c|c|}
\hline \multicolumn{2}{|l|}{ Gender } \\
\hline Man & $63.2 \%(n=23)$ \\
\hline Woman & $36.8 \%(n=13)$ \\
\hline \multicolumn{2}{|c|}{ Motivational Climate } \\
\hline Task oriented Climate & $\mathrm{M}=3.95(\mathrm{SD}=.70)$ \\
\hline Cooperative Learning & $M=4.02(S D=.78)$ \\
\hline Effort/Improvement & $\mathrm{M}=3.91(\mathrm{SD}=.68)$ \\
\hline Important Role & $\mathrm{M}=3.96(\mathrm{SD}=.83)$ \\
\hline Ego oriented Climate & $\mathrm{M}=2.30(\mathrm{SD}=.79)$ \\
\hline Rivalry between members of the group & $\mathrm{M}=2.65(\mathrm{SD}=.93)$ \\
\hline Punishment for mistakes & $\mathrm{M}=2.18(\mathrm{SD}=.83)$ \\
\hline Unequal Recognition & $M=2.25(S D=.91)$ \\
\hline Emotional Intelligence & $\mathrm{M}=3.84(\mathrm{SD}=.46)$ \\
\hline Emotion perception & $\mathrm{M}=3.80(\mathrm{SD}=.46)$ \\
\hline Self-emotional management & $\mathrm{M}=3.96(\mathrm{SD}=.53)$ \\
\hline Heteroemotional management & $\mathrm{M}=3.81(\mathrm{SD}=.51)$ \\
\hline Emotion utilisation & $\mathrm{M}=3.77(\mathrm{SD}=.55)$ \\
\hline
\end{tabular}

Statistical differences are not found when relating motivational climate in athletes with their gender $(p \geq .05)$ in task oriented climate and its categories, cooperative learning, effort/improvement and important role. However, when ego oriented climate is analysed we do find a connection ( $p \leq .05)$, corresponding higher figures to males, with an average value of $2.42(S D=.78)$, whereas girls have a median of $2.10(S D=.77)$. The same happens in categories such as rivalry between members of the group, punishment for mistakes and unequal recognition, where girls have lower scores than boys.

Statistical associations have not been found $(p \geq .05)$ when analysing emotional intelligence and its dimensions regarding gender of athletes, although a tendency towards slightly higher figures can be seen in men in general emotional intelligence and its dimensions, emotion perception, self-emotional management and heteroemotional management, whereas in the dimension of emotion utilisation these figures are reversed, finding higher scores in women. 
Table 2. Motivational climate and emotional intelligence regarding gender.

\begin{tabular}{|c|c|c|c|c|c|c|c|}
\hline & \multicolumn{4}{|c|}{ Gender } & & & \multirow{3}{*}{$\begin{array}{c}\text { T-Test } \\
\text { Sig. }\end{array}$} \\
\hline & \multicolumn{2}{|c|}{ Male } & \multicolumn{2}{|c|}{ Female } & \multicolumn{2}{|c|}{ Levene's test } & \\
\hline & $M$ & SD & M & SD & $\mathbf{F}$ & Sig. & \\
\hline Task Oriented Climate & 3.93 & .65 & 3.98 & .78 & 4.074 & .044 & .536 \\
\hline Cooperative Learning & 4.00 & .74 & 4.06 & .85 & 2.267 & .133 & .543 \\
\hline Effort//mprovement & 3.90 & .63 & 3.94 & .76 & 2.960 & .086 & .555 \\
\hline Important Role & 3.94 & .76 & 4.00 & .93 & 5.161 & .024 & .550 \\
\hline Ego Oreiented Climate & 2.42 & .78 & 2.10 & .77 & .403 & .526 & .000 \\
\hline Rivalry between members of the group & 2.82 & .88 & 2.36 & .94 & .371 & .543 & .000 \\
\hline Punishment for mistakes & 2.26 & .83 & 2.05 & .80 & .316 & .574 & .015 \\
\hline Unequal Recognition & 2.38 & .90 & 2.04 & .89 & .037 & .847 & .001 \\
\hline Emotional Intelligence & 3.86 & .49 & 3.82 & .40 & 5.768 & .017 & .495 \\
\hline Emotion Perception & 3.84 & .54 & 3.74 & .50 & 4.104 & .044 & .094 \\
\hline Self-emotional management & 3.97 & .51 & 3.93 & .47 & .690 & .407 & .512 \\
\hline Heteroemotional management & 3.83 & .54 & 3.78 & .46 & 1.957 & .163 & .406 \\
\hline Emotion utilisation & 3.73 & .59 & 3.84 & .48 & 9.093 & .003 & .055 \\
\hline
\end{tabular}

Relating motivational climate with the sport practised, no statistically significant differences are shown ( $p$ $\geq .05$ ) between motivational climate of athletes and the kind of sport practised in task oriented climate nor in its categories cooperative learning, effort/improvement and important role, neither in the ego oriented climate category unequal recognition. Nevertheless, in ego oriented climate and its categories rivalry between members of the group and punishment for mistakes there is a statistical association ( $p \leq .05)$, finding that athletes in the individual category with contact obtain the highest average values in ego oriented climate $(M=2.72 ; S D=.91)$ and in the categories rivalry between members of the group $(M=3.01 ; S .=.98)$ and punishment for mistakes $(M=2.62$; $S D=1.01)$, followed by individual sports without contact and collective without contact in ego oriented climate and its category rivalry between members of the group, and athletes who practise collective sports without contact in the category punishment for mistakes.

When emotional intelligence is analysed depending on the kind of sports practised, statistical connections have not been found $(p \geq .05)$ in general emotional intelligence nor its dimensions, emotion perception, heteroemotional management and emotion utilisation.

However, in the dimension self-emotional management, a statistical association does exist $(p=.036)$, finding that individuals who practise collective sports with contact obtain the highest scores in this dimension $(\mathrm{M}=4.03 ; \mathrm{SD}=.42)$, followed by athletes in individual categories without contact and collective with contact, showing both a median of 3.92; finally, athletes obtaining lower scores are the ones who practise individual sports with contact, with a median of $3.72(S D=.73)$. 
Table 3. Motivational climate and emotional intelligence regarding categories of sports.

\begin{tabular}{|c|c|c|c|c|c|c|c|c|c|c|}
\hline & \multicolumn{8}{|c|}{ Category of sports } & \multirow{4}{*}{$\mathbf{F}$} & \multirow{4}{*}{ Sig. } \\
\hline & \multicolumn{4}{|c|}{ Individual } & \multicolumn{4}{|c|}{ Collective } & & \\
\hline & \multicolumn{2}{|c|}{$\begin{array}{l}\text { Without } \\
\text { contact }\end{array}$} & \multicolumn{2}{|c|}{ With contact } & \multicolumn{2}{|c|}{$\begin{array}{l}\text { Without } \\
\text { contact }\end{array}$} & \multicolumn{2}{|c|}{$\begin{array}{l}\text { With } \\
\text { contact }\end{array}$} & & \\
\hline & M & SD & M & SD & M & SD & M & SD & & \\
\hline Ego oriented climate & 2.21 & .80 & 2.72 & .918 & 2.21 & .81 & 2.38 & .74 & .311 & .817 \\
\hline $\begin{array}{l}\text { Punishment for } \\
\text { mistakes }\end{array}$ & 2.11 & .80 & 2.62 & 1.01 & 2.08 & .81 & 2.25 & .82 & .910 & .436 \\
\hline Unequal recognition & 2.17 & .92 & 2.68 & 1.08 & 2.20 & .92 & 2.31 & .85 & .116 & .951 \\
\hline $\begin{array}{l}\text { Rivalry between } \\
\text { members of the } \\
\text { group }\end{array}$ & 2.52 & .93 & 3.01 & .98 & 2.52 & .89 & 2.81 & .90 & .379 & .768 \\
\hline $\begin{array}{l}\text { Task oriented } \\
\text { climate }\end{array}$ & 3.82 & .46 & 3.80 & .44 & 3.86 & .46 & 3.89 & .49 & 3.048 & .029 \\
\hline Cooperative learning & 3.74 & .54 & 3.78 & .50 & 3.84 & .52 & 3.90 & .53 & 3.282 & .010 \\
\hline Effort/ Improvement & 3.92 & .50 & 3.87 & .52 & 3.99 & .47 & 4.03 & .51 & 2.686 & .046 \\
\hline \multirow[t]{5}{*}{ Important role } & 3.80 & .52 & 3.81 & .46 & 3.82 & .52 & 3.84 & .54 & 1.958 & .120 \\
\hline & \multicolumn{8}{|c|}{ Category of sports } & & \\
\hline & \multicolumn{4}{|c|}{ Individual } & \multicolumn{4}{|c|}{ Collective } & $F$ & Sia \\
\hline & \multicolumn{2}{|c|}{$\begin{array}{l}\text { Without } \\
\text { contact }\end{array}$} & \multicolumn{2}{|c|}{ With contact } & \multicolumn{2}{|c|}{$\begin{array}{l}\text { Without } \\
\text { contact }\end{array}$} & \multicolumn{2}{|c|}{$\begin{array}{l}\text { With } \\
\text { contact }\end{array}$} & & \\
\hline & M & SD & M & SD & M & SD & M & SD & & \\
\hline $\begin{array}{l}\text { Emotional } \\
\text { Intelligence }\end{array}$ & 3.82 & .43 & 3.67 & .67 & 3.81 & .52 & 3.90 & .44 & 1.852 & .137 \\
\hline Emotion perception & 3.77 & .50 & 3.60 & .76 & 3.76 & .55 & 3.88 & .51 & 2.261 & .081 \\
\hline $\begin{array}{c}\text { Self-emotional } \\
\text { management }\end{array}$ & 3.92 & .48 & 3.72 & .73 & 3.92 & .59 & 4.03 & .42 & 2.878 & .036 \\
\hline $\begin{array}{c}\text { Heteroemotional } \\
\text { management }\end{array}$ & 3.79 & .48 & 3.70 & .77 & 3.77 & .51 & 3.87 & .51 & .990 & .397 \\
\hline Emotion utilisation & 3.76 & .53 & 3.68 & .59 & 3.80 & .68 & 3.78 & .55 & .237 & .871 \\
\hline
\end{tabular}

Analysis of correlation between emotional intelligence and task oriented climate shows significant correlation $(p \leq .01)$ between them. General emotional intelligence and its dimensions emotion perception, selfemotional management, heteroemotional management and emotion utilisation correlate directly with task oriented climate and its categories cooperative learning, effortimprovement and important role. 
Table 4. Correlation between Emotional Intelligence and Task oriented Climate.

\begin{tabular}{ccccccccc} 
& EP & SEM & HEM & EU & TC & TCCL & CTEI & TCIR \\
\hline EI & $.921^{*}$ & $.903^{*}$ & $.919^{*}$ & $.741^{*}$ & $.433^{*}$ & $.369^{*}$ & $.413^{*}$ & $.422^{*}$ \\
\hline EP & & $.806^{*}$ & $.780^{*}$ & $.598^{*}$ & $.380^{*}$ & $.313^{*}$ & $.359^{*}$ & $.383^{*}$ \\
\hline SEM & & & $.741^{*}$ & $.600^{*}$ & $.419^{*}$ & $.375^{*}$ & $.397^{*}$ & $.397^{*}$ \\
\hline HEM & & & $.609^{*}$ & $.393^{*}$ & $.337^{*}$ & $.373^{*}$ & $.383^{*}$ \\
\hline EU & & & & $.320^{*}$ & $.259^{*}$ & $.319^{*}$ & $.304^{*}$ \\
\hline TC & & & & & $.920^{*}$ & $.952^{*}$ & $.924^{*}$ \\
\hline TCCL & & & & & & $.825^{*}$ & $.802^{*}$ \\
\hline TCEI & & & & & & & $.795^{*}$ \\
\hline
\end{tabular}

Note: ${ }^{*} \leq \leq$.01. El=Emotional Intelligence. EP=Emotion Perception. SEM=Self-emotional management. HEM=Heteroemotional

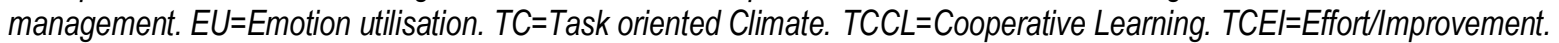
TCIR=Important Role.

On the other hand, analysis of correlation between emotional intelligence and ego oriented climate shows that emotional intelligence does not correlate with ego oriented climate, coming to the conclusion that there is no relation between levels of athletes' emotional intelligence and ego oriented motivation.

Table 5. Correlation between Emotional Intelligence and Ego oriented Climate.

\begin{tabular}{|c|c|c|c|c|c|c|c|c|}
\hline & El & SEM & HEM & EU & EC & ECRMG & ECPM & ECUR \\
\hline EI & $.921^{*}$ & $.903^{*}$ & $.919^{*}$ & $.741^{*}$ & -.046 & .015 & -.075 & -.040 \\
\hline EP & & $.806^{*}$ & $.780^{*}$ & $.598^{*}$ & -.050 & .032 & -.076 & -.055 \\
\hline SEM & & & $.741^{*}$ & $.600^{*}$ & -.059 & -.007 & -.100 & -.035 \\
\hline HEM & & & & $.609^{*}$ & -.008 & .047 & -.032 & -.011 \\
\hline EU & & & & & -.072 & -.066 & -.071 & -.058 \\
\hline EC & & & & & & $.757^{*}$ & $.913^{*}$ & $.945^{*}$ \\
\hline ECRMG & & & & & & & $.579^{*}$ & $.615^{*}$ \\
\hline ECPM & & & & & & & & $.781^{*}$ \\
\hline
\end{tabular}

Note: ${ }^{*} p \leq .01$. EP=Emotional Intelligence. EP=Emotion Perception., SEM=Self-emotional management. HEM=Heteroemotional management. EU=Emotion utilisation. $E C=E g o$ oriented Climate. ECRMG=Rivalry Members of Group. ECPM=Punishment for mistakes. ECUR= Unequal recognition.

\section{DISCUSSION}

In this research study performed on a sample of 372 athletes, regarding emotional intelligence, dimensions obtaining higher scores have been self-emotional management, followed by heteroemotional management and emotion perception, therefore obtaining emotion utilisation the lowest marks. These data are similar to those obtained by Bekendam (2013) and Pérez (2012), being emotion utilisation the lowest rated emotional 
intelligence dimension. In return, Lezcano (2016) showed higher values of emotion perception in young football players, corresponding the lower figures to self-emotional management.

When connecting motivational climate with athletes' gender, differences between ego oriented climate and its categories are verified, finding greater orientation towards this type of motivation in men. These data coincide with all studies consulted (Lochbaum Kallinen \& Konttinen, 2017; Martin, Gould \& Ewing, 2017; Moreno-Murcia, Marcos-Pardo \& Huescar, 2016; Moyano, Pacheco, \& Urbieta, 2018; Sosik, Chun \& Koul, 2017; Zurita, Zafra, Valdivia, Rodríguez, Castro, \& Muros, 2017). These differences related to athletes' gender can be understood through different social variables which influence decisively the kind of socialization within sport in men and women, understanding that the latter interpret sport as a cooperative activity aimed at occupying free time and improving physical abilities and composition, whereas men focus on the competitive side of the activity (Castro-Sánchez, Zurita-Ortega, Chacón-Cuberos, Martínez-Martínez, Espejo-Garcés, \& Álvaro-González, 2015; Stanger et al., 2017).

As regards relationships between emotional intelligence and athletes' gender, statistical association has not been found, although there is a tendency towards slightly higher values in men in general emotional intelligence and its dimensions, emotion perception, self-emotional management and heteroemotional management, whereas in emotion utilisation figures are reversed, finding higher scores in women. In this respect different research studies with contradictory results are found, coinciding data obtained with those found in research by Inglés, Torregrosa, García-Fernández, Martínez-Monteagudo, Estévez, \& Delgado (2014). Nevertheless, they differ with data found by Pineda (2012), Trigoso (2013) \& Ysern (2016) finding higher levels of emotional abilities such as ability to recognise and understand feelings, while boys manage self-emotions more effectively.

The kind of instrument used to assess emotional intelligence in research participants can influence data, as men are able to recognise and manage emotions more effectively, while women use emotions more efficiently. Results can be explained in terms of women being more emotional, tending to focus on and pay attention to their feelings and emotions, considered as an adaptive style responding to educational standards socially and culturally acquired, thus being more effective in controlling their feelings and emotions, while men are less accurate when recognising and managing these emotions (Helpman, Penso, Zagoory-Sharon, Feldman \& Gilboa-Schechtman, 2017). These data indicate the non-existence of differences between genders, which seems to show that differences between sexes are currently being eliminated, perhaps being sport an egalitarian element (Alsarve, 2017).

Concerning motivation, analysed athletes show a clear orientation towards task, obtaining much higher ratings in this category and its subcategories (cooperative learning, effort/improvement and important role), obtaining lower scores in ego climate and its categories (rivalry between members of the group, punishment for mistakes and unequal recognition). Figures obtained indicate a clear interest of the athletes in focusing on personal effort and self-improvement, developing a love for sports, as well as trying to improve technicaltactical aspects related to their sport in order to improve performance, key feature in self-determinated motivation (Vink, Raudsepp, \& Kais, 2015).

These results coincide with all the consulted investigations in the context of sports, which indicate the existence of a higher orientation towards task (Álvarez, López, Gómez, Brito \& González, 2017; Chacón, Zurita, Castro, Espejo, Martínez, \& Pérez, 2017; Garcia-Mas, Fuster-Parra, Ponseti, Palou, Olmedilla, \& Cruz, 2015; Gutiérrez, 2014; Meroño, Calderón, \& Hastie, 2016). Data can be understood regarding the source of the sampling, being most athletes non-professional or amateur, finding a scarce number of 
professional or semi-professional athletes. If the sampling was solely composed of high-performance athletes, figures relative to ego climate would be higher, due to the fact that in this context, achieving success and recognition is more important, being in this case motivation less self-determinated (Alfermann, Geiser, \& Okade, 2013; Shrout, Voelker, Munro \& Kubitz, 2017).

Concerning motivation based on kind of sports practised, this investigation has found that athletes with a higher orientation towards ego are those who practise individual sports with contact, whereas those who practise collective sports obtain lower scores in ego oriented motivation. In this sense, following Almagro's hypothesis (2012), investigations analysing motivational differences regarding kind of sports are scarce, finding research by Montero, Moreno, González-Cutre \& Sicilia (2007), whose results differ from those found in this investigation, they analysed existing differences between athletes from individual and collective categories, observing a higher orientation towards ego in athletes in collective categories, whereas athletes in individual categories had a higher orientation towards task.

Along the same lines, Hanrahan \& Biddle (2002) found higher orientation towards task in track and field athletes, whereas football and basketball players were more ego oriented. Results found in this doctoral thesis show that athletes in the individual category with contact are more ego oriented than those practising collective sports, due to the fact that direct confrontation between rivals makes athletes base success on achievement of goals, thus being the category of sports a decisive factor in motivation and compromise towards sport (Wikman et al., 2018). Although these results might be due to sampling features, finding little representation of this group with higher competitive levels than the rest of categories.

When levels of emotional intelligence regarding category of sports were analysed, only differences in selfemotional management were found, being athletes in collective categories with contact who better manage their emotions, unlike athletes in individual categories with contact who are the worst in managing them. These data coincide with those obtained by Martin (2013) in his doctoral thesis, indicating that although differences are not significant, we can see higher levels of emotional intelligence in individuals who practise collective sports versus those who practise individual sports, although no more studies have been found analysing differences in emotional intelligence depending on category of sports practised.

These results might be due to the acquisition and development of better social abilities by athletes in collective categories with contact, owing to interaction with other members of the team and rivals, these abilities not being found in athletes who practise individual sports as they do not interact with team mates. These data show the need to carry on with investigations in these lines, due to the scarcity of data found regarding results obtained in this investigation, which show a direct connection between category of sports practised and ability to manage self-emotions.

Results in this investigation reveal the existence of positive and significant correlations between more selfdeterminated types of motivation (task oriented climate) and levels of emotional intelligence, while extrinsic motivation is not related to emotional intelligence in any way. Correlation coefficients are moderate, such as those found in studies by Cera, Almagro, Conde, \& Sáenz-López (2015), Conde, Sáenz-López, \& MorenoMurcia (2013), and Núñez, León, González, \& Martín-Albo (2011), therefore needing these data revision in subsequent studies. However, in Gutiérrez \& Ibañez's study (2017), high levels of correlation are shown, which confirm these relations.

There is a significant and positive relation between task climate and emotional intelligence, supporting the connection between intrinsic motivation and positive and pleasant feelings and emotions, favouring the 
intention of practising sports (García-Bengoechea, Sabiston, Ahmed, \& Farnoush, 2010). This suggests the need to promote motivational climates oriented towards task by coaches aiming at favouring the practice of sport and the athletes' enjoyment, as well as effort and personal self-improvement (Stenling, Lindwall, \& Hassmén, 2015).

Control of emotions positively affects athlete's motivational orientation, associating higher levels of emotional intelligence with a more self-determinated motivation where the person does not aim at succeeding through external rewards and outperformance of rivals and peers, but acts just because of the pleasure of practising sports and the improvement of his abilities, focusing on effort and personal self-improvement (Hogue, Fry \& Fry, 2017).

In line with this, Allan \& Coté (2016) highlight the importance of transmitting emotions by the coach, these highly affecting his athletes' behaviour, which can directly influence the attachment to sport and a greater satisfaction derived from it (Jekauc, 2015). The context of sports is a great generator of emotions, which is ideal in order to work on and educate in emotional intelligence (Lee, Kwon, \& Oh, 2016). Along these lines, there are studies such as the one by Fernández-Ozcorta, Almagro, \& Sáenz-López (2015) that analyse relations between emotional intelligence and the practice of physical activity, coming to the conclusion that physically active people obtain higher values in emotional intelligence, finding more positive emotions.

\section{CONCLUSIONS}

The main conclusions drawn from this research study are the clear orientation of the athletes analysed towards task, being orientation towards ego greater in men and standing out orientation towards task in athletes of individual categories with contact. Regarding emotional intelligence, athletes studied presented high values in the four dimensions, being self-emotional management the one receiving higher scores, whereas emotion utilisation has been the one receiving the lowest rating; additionally no connection has been found between emotional intelligence and gender of the respondents; regarding categories of sports, athletes practising collective sports with contact are the best at managing their emotions. Emotional intelligence correlates directly and significantly with motivational climate oriented towards task, but does not with ego climate.

This research study has some limitations, including among them the nature of the study, being descriptive and cross-sectional, so it would have been interesting to carry out a study regarding different moments in the competition season in order to observe relations between motivational and emotional factors.

This study brings forward relevant data concerning relations between motivational climate of athletes and their levels of emotional intelligence, showing a clear connection between higher levels of emotional intelligence in individuals with a clear orientation towards task, revealing the need to implement intervention programmes in order to promote self-determinated motivation in the context of sports.

\section{REFERENCES}

Alfermann, D., Geisler, G., y Okade, Y. (2013). Goal orientation, evaluative fear, and perceived coach behavior among competitive youth swimmers in Germany and Japan. Psychology Sport and Exercise, 14(3), 307-315. https://doi.org/10.1016/j.psychsport.2012.11.005 
Allan, V., y Côté, J. (2016). A cross-sectional analysis of coaches' observed emotion-behavior profiles and adolescent athletes' self-reported developmental outcomes. Journal of Applied Sport Psychology, 28(3), 321-337. https://doi.org/10.1080/10413200.2016.1162220

Almagro, B. J. (2012). Factores motivacionales relacionados con la adherencia a la práctica deportiva competitiva en adolescentes. Tesis doctoral: Universidad de Huelva.

Alsarve, D. (2017). Addressing gender equality: enactments of gender and hegemony in the educational textbooks used in Swedish sports coaching and educational programmes. Sport, Education and Society, 22, 1-13. https://doi.org/10.1080/13573322.2017.1280012

Álvarez, E. F., López, J. C., Gómez, V., Brito, J. y González, H. A. (2017). Influencia de la motivación y del flow disposicional sobre la intención de realizar actividad físico-deportiva en adolescentes de cuatro países. Retos, 31, 46-51.

Ames, C. (1992). Achievement goals, motivational climate, and motivational processes. En Roberts, G. (Ed.), Motivation in sport and exercise (pp. 161-176). Champaign, IL: Human Kinetics.

Anshel, M. y Payne, J. (2006). Application of Sport Psychology for Optimal Performance in Martial Arts, en J. Dosil (ed.), The Sport Psychologist's Handbook (pp. 353-374). UK: John Wiley \& Sons.

Balk, Y. A., De Jonge, J., Oerlemans, W. G., y Geurts, S. A. (2017). Testing the triple-match principle among Dutch elite athletes: A day-level study on sport demands, detachment and recovery. Psychology of Sport and Exercise, 33, 7-17. https://doi.org/10.1016/i.psychsport.2017.07.006

Bekendam, N. (2013). Diferencias en inteligencia, inteligencia emocional y personalidad entre nadadores y sujetos sedentarios. Tesis doctoral: Universidad Europea de Madrid.

Bennett, J., y Maynard, I. (2017). Performance blocks in sport: Recommendations for treatment and implications for sport psychology practitioners. Journal of Sport Psychology in Action, 8(1), 60-68. https://doi.org/10.1080/21520704.2016.1227414

Castro-Sánchez, M., Zurita-Ortega, F., Chacón-Cuberos, R., Martínez-Martínez, A., Espejo-Garcés, T. y Álvaro-González, J. (2015). Sustancias nocivas y clima motivacional en relación a la práctica de actividad física. Salud y drogas, 15(2), 115-126. https://doi.org/10.21134/haaj.v15i2.244

Cera, E., Almagro, B., Conde, C. y Sáenz-López, P. (2015). Inteligencia emocional y motivación en educación física en secundaria. Retos, 27, 8-13.

Chacón, R., Zurita, F., Castro, M., Espejo, T., Martínez, A. y Pérez, A. (2017). Clima motivacional hacia el deporte y su relación con hábitos de ocio digital sedentario en estudiantes universitarios. Saúde e Sociedade, 26(1), 29-39. https://doi.org/10.1590/s0104-12902017166561

Conde, C., Sáenz-López, P. y Moreno-Murcia, J. A. (2013). Un estudio de casos sobre la transmisión de un clima tarea en el deporte. Revista Internacional de Medicina y Ciencias de la Actividad Física y el Deporte, 13(50), 329-344.

Elliff, H. y Huertas, J. (2015). Classroom motivational climate: in search of nuances. Revista de Psicología, 11(21), 61-74. https://doi.org/10.5093/ed2010v16n2a3

Fernández-Ozcorta, E. J., Almagro, B. J. y Sáenz-López, P. (2015). Inteligencia emocional percibida y el bienestar psicológico de estudiantes universitarios en función del nivel de actividad física. Cultura, Ciencia y Deporte, 10(28), 31-39. https://doi.org/10.12800/ccd.v10i28.513

García-Bengoechea, E. G., Sabiston, C. M., Ahmed, R., y Farnoush, M. (2010). Exploring links to unorganized and organized physical activity during adolescence: The role of gender, socioeconomic status, weight status, and enjoyment of physical education. Research Quarterly for Exercise and Sport, 81, 7-16. https://doi.org/10.5641/027013610X13352775119475

García-Coll, V., Graupera-Sanz, J. L., Ruiz-Pérez, L. y Palomo-Nieto, M. (2013). Inteligencia emocional en el deporte: Validación española del Schutte Self Report Inventory (SSRI) en deportistas españoles. Cuadernos de Psicología del Deporte, 13(1), 25-36. https://doi.org/10.4321/S1578$\underline{84232013000100004}$ 
Garcia-Mas, A., Fuster-Parra, P., Ponseti, F. J., Palou, P., Olmedilla, A. y Cruz, J. (2015). Análisis bayesiano de la motivación, el clima motivacional y la ansiedad en jóvenes jugadores de equipo. Anales de psicología, 31(1), 355-366. https://doi.org/10.6018/analesps.31.1.167531

González-Cutre, D., Sicilia, A., y Moreno, J. A. (2008). Modelo cognitivo-social de la motivación de logro en educación física. Psicothema, 20(4), 642-651.

Gutiérrez, M. (2014). Relaciones entre el clima motivacional, las experiencias en educación física y la motivación intrínseca de los alumnos. Retos. Nuevas tendencias en Educación Física, Deporte y Recreación, 26, 9-14.

Gutiérrez, M. e Ibáñez, R. (2017). El profesor de educación física y la inteligencia emocional. International Journal of Developmental and Educational Psychology, 3(1), 419-424. https://doi.org/10.17060/ijodaep.2017.n1.v3.1010

Hacker, C. M., y Mann, M. E. (2017). Talking across the divide: Reflections and recommendations for context-driven, cultural sport psychology. Journal of Sport Psychology in Action, 8(2), 76-86. https://doi.org/10.1080/21520704.2017.1287144

Hanrahan, S. J., y Biddle, S. J. H. (2002). Measurement of achievement orientations: Psychometric measures, gender, and sport differences. European Journal of Sport Science, 2(5), 1-12. https://doi.org/10.1080/17461390200072502

Helpman, L., Penso, J., Zagoory-Sharon, O., Feldman, R., y Gilboa-Schechtman, E. (2017). Endocrine and emotional response to exclusion among women and men; cortisol, salivary alpha amylase, and mood. Anxiety, Stress, \& Coping, 30(3), 253-263. https://doi.org/10.1080/10615806.2016.1269323

Hogue, C. M., Fry, M. D., y Fry, A. C. (2017). The differential impact of motivational climate on adolescents' psychological and physiological stress responses. Psychology of Sport and Exercise, 30, 118-127. https://doi.org/10.1016/i.psychsport.2017.02.004

Holden, S. L., Pugh, S. F., y Schwarz, N. A. (2017). Achievement Motivation of Collegiate Athletes for Sport Participation. International Journal of Sports Science, 7(2), 25-28.

Inglés, C., Torregrosa, M., García-Fernández, J., Martínez-Monteagudo, M., Estévez, E. y Delgado, B. (2014). Conducta agresiva e inteligencia emocional en la adolescencia. European Journal of Education and Psychology, 7(1), 29-41. https://doi.org/10.30552/ejep.v7i1.97

Jekauc, D. (2015). Enjoyment during exercise mediates the effects of an intervention on exercise adherence. Psychology, 6(1), 48-54. https://doi.org/10.4236/psych.2015.61005

Lee, Y. H., Kwon, H. H. y Oh, H. (2016). Emotional laour in teaching secondary physical education. International Journal of Kinesiology and Sports Science, 4(2), 1-10. https://doi.org/10.7575/aiac.ijkss.v.4n.2p.1

Lezcano, R. (2016). Influencia de los estilos educativos y las características psicoemocionales en el desarrollo de jóvenes futbolistas de élite. Tesis doctoral: Universidad Camilo José Cela.

Lochbaum, M., Kallinen, V., y Konttinen, N. (2017). Task and Ego Goal Orientations across the Youth Sports Experience. Studia sportiva, 11(2), 99-105. https://doi.org/10.5817/StS2017-2-10

Martin, E. M., Gould, D., y Ewing, M. E. (2017). Youth's perceptions of rule-breaking and antisocial behaviours: Gender, developmental level, and competitive level differences. International Journal of Sport and Exercise Psychology, 15(1), 64-79. https://doi.org/10.1080/1612197X.2015.1055289

Martín, M. (2013). Análisis de un modelo estructural de inteligencia emocional y motivación autodeterminada en el deporte. Tesis doctoral: Universidad de Valencia.

McConville, J., McAleer, R., y Hahne, A. (2017). Mindfulness training for health profession students-the effect of mindfulness training on psychological well-being, learning and clinical performance of health professional students: a systematic review of randomized and non-randomized controlled trials. Explore: The Journal of Science and Healing, 13(1), 26-45. https://doi.org/10.1016/.explore.2016.10.002 
Meroño, L., Calderón, A. y Hastie, P. A. (2016). Effect of a Sport Education season on the technical learning and motivational climate of junior high performance swimmers. RICYDE. Revista Internacional de Ciencias del Deporte, 12(44), 182-198. https://doi.org/10.5232/ricyde2016.04407

Montero, C., Moreno, J., González, D. y Cervelló, E. (2013). Motivación, dirección de la autoconfianza y flow en judokas de alto nivel. European Journal of Human Movement, 31, 1-12.

Moreno-Murcia, J. A., Marcos-Pardo, P. J. y Huéscar, E. (2016). Motivos de práctica físico-deportiva en mujeres: diferencias entre practicantes y no practicantes. Revista de Psicología del deporte, 25(1), 35-41.

Moyano, A. C., Pacheco, M. M. y Urbieta, C. T. (2018). Procesos psicosociales en Educación Física: actitudes, estrategias y clima motivacional percibido (Psychosocial processes in Physical Education: attitudes, strategies, and perceived motivational climate). Retos, 34, 19-24.

Newton, M., Duda, J. L., y Yin, Z. (2000). Examination of the psychometric properties of the Perceived Motivational Climate in Sport Questionnaire-2 in a sample of female athletes. Journal of Sports Sciences, 18, 275-290. https://doi.org/10.1080/026404100365018

Núñez, J. L., León, J., González, V. y Martín-Albo, J. (2011). Propuesta de un modelo explicativo del bienestar psicológico en el contexto deportivo. Revista de Psicología del Deporte, 20, 223-242.

Ong, N. C., y Griva, K. (2017). The effect of mental skills training on competitive anxiety in schoolboy rugby players. International Journal of Sport and Exercise Psychology, 15(5), 475-487. https://doi.org/10.1080/1612197X.2016.1153129

Pérez, A. (2012). Inteligencia emocional y motivación en el estudiante universitario. Tesis doctoral: Universidad de Las Palmas de Gran Canaria.

Pineda, C. (2012). Inteligencia emocional y bienestar personal en estudiantes universitarios de ciencias de la salud. Tesis doctoral: Universidad de Málaga.

Quested, E., Ntoumanis, N., Thøgersen-Ntoumani, C., Hagger, M. S., y Hancox, J. E. (2017). Evaluating quality of implementation in physical activity interventions based on theories of motivation: Current challenges and future directions. International Review of Sport and Exercise Psychology, 10(1), 252269. https://doi.org/10.1080/1750984X.2016.1217342

Rodríguez, J. E., Gómez, J. A. y Álvarez, J. M. (2017). Papel del Psicólogo en el deporte. Roca. Revista Científico-Educacional de la provincia Granma, 10(4), 28-34.

Schutte, N. S., Malouff, J. M., Hall, L. E., Haggerty, D. J., Cooper, J. T., Golden, Ch. J. y Dornhein, L. (1998). Development and validation of a measure of emotional intelligence. Personality and Individual Differences, 25(2), 167-177. https://doi.org/10.1016/S0191-8869(98)00001-4

Shrout, M. R., Voelker, D. K., Munro, G. D., y Kubitz, K. A. (2017). Associations Between Sport Participation, Goal and Sportspersonship Orientations, and Moral Reasoning. Ethics \& Behavior, 27(6), 502-518. https://doi.org/10.1080/10508422.2016.1233494

Sosik, J. J., Chun, J. U., y Koul, R. (2017). Relationships between psychological wellbeing of thai college students, goal orientations, and gender. Psychology in the Schools, 54(7), 703-717. https://doi.org/10.1002/pits.22024

Stanger, N., Kavussanu, M., y Ring, C. (2017). Gender moderates the relationship between empathy and aggressiveness in sport: The mediating role of anger. Journal of Applied Sport Psychology, 29(1), 44-58. https://doi.org/10.1080/10413200.2016.1196764

Stenling, A., Ivarsson, A., Hassmén, P. y Lindwall, M. (2017). Longitudinal associations between athletes' controlled motivation, ill-being, and perceptions of controlling coach behaviors: A Bayesian latent growth curve approach. Psychology of Sport and Exercise, 30, 205-214. https://doi.org/10.1016/i.psychsport.2017.03.002 
Super, S., Verkooijen, K., y Koelen, M. (2018). The role of community sports coaches in creating optimal social conditions for life skill development and transferability-a salutogenic perspective. Sport, education and society, 23(2), 173-185. https://doi.org/10.1080/13573322.2016.1145109

Thelwell, R. C., Wood, J., Harwood, C., Woolway, T., y Van Raalte, J. L. (2018). The role, benefits and selection of sport psychology consultants: Perceptions of youth-sport coaches and parents. Psychology of Sport and Exercise, 35, 131-142. https://doi.org/10.1016/j.psychsport.2017.12.001

Trigoso, M. (2013). Inteligencia emocional en jóvenes y adolescentes españoles y peruanos: variables psicológicas y educativas. Tesis doctoral: Universidad de León.

Vink, K., Raudsepp, L., y Kais, K. (2015). Intrinsic motivation and individual deliberate practice are reciprocally related: Evidence from a longitudinal study of adolescent team sport athletes. Psychology of Sport and Exercise, 16, 1-6. https://doi.org/10.1016/j.psychsport.2014.08.012

Wallhead, T. L., Garn, A. C., y Vidoni, C. (2014). Effect of a Sport Education Program on Motivation for Physical Education and Leisure-Time Physical Activity. Research quarterly for exercise and sport, 85(4), 478-487). https://doi.org/10.1080/02701367.2014.961051

Weinberg, R. S., y Gould, D. (2010). Fundamentos de psicología del deporte y del ejercicio físico. Madrid: Médica Panamericana.

Wikman, J. M., Elsborg, P., Nielsen, G., Seidelin, K., Nyberg, M., Bangsbo, J., Hellsten, Y., y Elbe, A. M. (2018). Are team sport games more motivating than individual exercise for middle-aged women? A comparison of levels of motivation associated with participating in floorball and spinning. Kinesiology, 50(1), 1-9.

Ysern, L. (2016). Relación entre la inteligencia emocional, recursos y problemas psicológicos, en la infancia y adolescencia. Tesis doctoral: Universidad de Valencia.

Zurita, F., Zafra, E., Valdivia, P., Rodríguez, S., Castro, M. y Muros, J. J. (2017). Análisis de la resiliencia, autoconcepto y motivación en judo según el género. Revista de Psicología del Deporte, 26(1), 7181.

\section{(9) $\odot \Theta \Theta$}

This title is licensed under a Creative Commons Attribution-NonCommercial-NoDerivs 4.0 Unported License. 